\title{
Evaluation of drought stress tolerance in advanced barley cultivars in Sistan region
}

\author{
Fatemeh Sefatgol and Hamidreza Ganjali* \\ Department of Agriculture, Islamic Azad University, Zahedan Branch, Zahedan, Iran
}

\begin{abstract}
A separate experiment was conducted in a randomized complete block design with four replications in Agricultural Research Center of Sistan in 2014-15 crop year to investigate the effects of drought stress at the end of season on yield, yield components and stress assessment indicators in 10 barley lines. To apply drought stress, after 50\% emergence of cluster, irrigation was cut until the harvest. But irrigation was done in normal conditions until the end of the growing season and traits such as kernel yield, kernel per cluster, Thousand Kernel Weight (TKW), cluster length and plant height were measured. Barley lines had different reactions to the two conditions. Drought stress reduced yield and yield components. MP, GMP, HARM, SSI, TOL and STI indices were also evaluated. Results showed that the Lign and Brs180 lines were most resistant to the optimum and stress conditions and Lign line performed well in optimal conditions. MP, GMP, HARM and SSI indices showed a high correlation with kernel yield under irrigation and stress conditions. They were the most suitable indices in both conditions given the correlation between drought resistance indices.
\end{abstract}

KEY WORDS: DROUGHT STRESS, STRESS INDICES, BARELY YIELD

\section{INTRODUCTION}

Generally, stress is defined as any change in environmental conditions which leads to loss or adverse changes in an action or in other words, refers to any change in environmental conditions that makes plant's reaction out of appropriate or optimal condition. Environmental stresses are divided into two categories: biological stress and physicochemical stress. Biological stress caused by pests attack and diseases in plants and competing with other organisms that is mostly related to pathology and ecology. Physicochemical stresses are divided into five main categories: drought, temperature, radiation, chemical and mechanical tensions, of which the drought

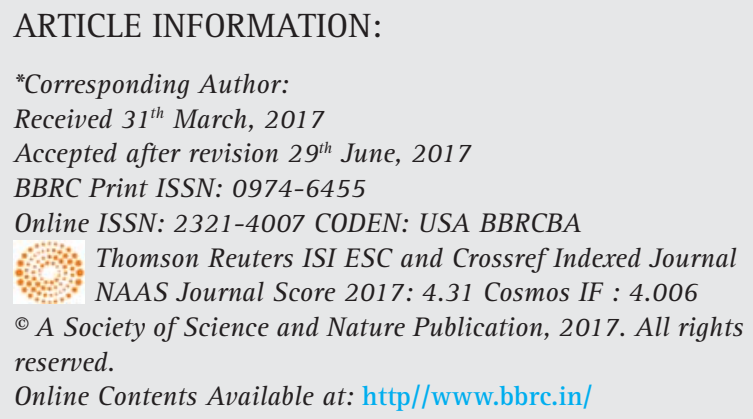


tension, salinity and temperature tensions are widespread in the world and hence have been studied more (Lovitee, 2000 Ata Sheikh 2005; Javadi et al, 2017).

Drought stress does not have the same effect on all aspects of plant growth thus some processes are very sensitive to increased drought stress that means the response of plants to drought stress is different and depends on plant growth stage where drought occurs (Brad ford 2004). Drought stress has a major impact on plant phenological and morphological traits. Drought stress delays the formation of yield components and performance is decreased by reducing the number of grains and grain weight (Inuy ama, 2000). Water shortages in the pollination stage cause reduction of seed numbers in most grains yield loss occurs during pregnancy or pollination. Barley is most susceptible to drought stress during stem elongation, pregnancy and spike emergence and if drought stress occurs in this stage yield loss will be the highest. This suggests that the timing of flowering and pollination is the most sensitive developmental period of barely to drought (Bidinger et al, 2000).

In this study, the growth of the five barley cultivars to drought stress were monitored, drought stress before pollination delayed phonological growth while drought after pollination stage (maturity date) accelerated phonological growth. Also drought stress duration had different effects on each growing stages. Early season stress, delayed pollination time and physiologic maturity whereas stress during flowering and final stage (in the aggregation) shortened grain filling period to 10 to 11 days (Simane et al, 2003; Fard et al., 2017).

In a study on several varieties of barley studying the relationship between yield and number of morphological, phenological and physiological property is expressed under final drought stress that genotypes having a longer growth period and shorter grain filling are suitable for cultivation in arid areas (Ortiz-Ferrara et al, 2001). The aim of this study was to investigate the effects of drought in the end of season on yield, yield components and stress assessment indicators in 10 barley lines, separate experiments are conducted in Sistan Agricultural Research Center in the 2014-2015 crop year.

\section{MATERIAL AND METHODS}

Type of plants used consists of advanced barley genotypes provided from Karaj Seed and Plant Improvement Research Institute.

Specifications of testing plan: to evaluate enhanced drought tolerance in barley cultivars in Sistan region, this experiment is done in a basic design of randomized complete block with four replications. Test treatments included 10 varieties of barley $(\mathrm{b} 1, \mathrm{~b} 2, \mathrm{~b} 3, \mathrm{~b} 4, \mathrm{~b} 5, \mathrm{~b} 6$, $\mathrm{b} 7, \mathrm{~b} 8, \mathrm{~b} 9, \mathrm{~b} 10)$ which in normal moisture conditions and drought stress conditions were analyzed separately. Experimental design map is shown in Table 2.

\section{RESULTS AND DISCUSSION}

3-1. The effect of measured traits of barley cultivars in normal conditions

The results of the variance analysis data show significant differences between cultivars in plant height in normal conditions at five percent statistical level (Table 1).

3-2. The effect of measured barley traits under drought stress

Plant height is one of the traits that is affected by agronomic factors, and changes treatments. The results of the data variance analysis show that there is significant difference between cultivars in plant height in drought stress conditions in a five percent statistical level (Table 2).

Highest bush height is for Violeta with an average height of $25.87 \mathrm{~cm}$ the and the lowest is for Merzaga with an average height of $25.79 \mathrm{~cm}$ (Figure 1).

Plant height: Plant height decreased with increasing drought stress can be impaired to deficit photosynthesis

\begin{tabular}{|l|l|l|}
\hline \multicolumn{3}{l}{ Table 1. Name and properties for genotypes } \\
\hline Entry & No & Pedigree \\
\hline 1 & Cheek & Zahak \\
\hline 2 & 3 & Lignee 527/ NK1272/ jLB70-63/3/L. 527//Chn-01/ Gostoe/4/Rhn-08/3/Deir Alla 106/D17/Karoon \\
\hline 3 & 6 & Comp- 1-71-E/1- BC-80320 \\
\hline 4 & 8 & Trompillo/ Beecher \\
\hline 5 & 9 & Merzaga (Orge0077) Alanda-01 \\
\hline 6 & 10 & VIOLETA/MJA// (LIGEE640/P1382758/DC- B/3/MOLA/4/LINO) \\
\hline 7 & 11 & Kavir/Badia/ 1-BC-80073 \\
\hline 8 & 12 & L.1242/Hesk/5/Mola/Shyri/Arupo*2/JET/3/Aleli/4/Mola/... \\
\hline 9 & 13 & SHENMAI NO.3/MSEL/CANELA \\
\hline 10 & 14 & BRS180/M98.77/6/P. STO/3/LBIRAN/UNA80/ LIGNEE640/4/BLLU/5/ PETUNIA1 \\
\hline
\end{tabular}




\begin{tabular}{|l|l|l|l|l|l|l|l|l|l|l|}
\hline \multicolumn{1}{|c|}{ Table 2. Experimental design map } \\
\begin{tabular}{|l|l|l|l|l|l|l|l|l|l|l|}
\hline R2 & b1 & b2 & b3 & b4 & b5 & b6 & b7 & b8 & b9 & b10 \\
\hline & \multicolumn{10}{|c|}{} \\
\hline R1 & b10 & b8 & b6 & b4 & b2 & b1 & b5 & b9 & b3 & b7 \\
\hline & \multicolumn{10}{|c|}{} \\
\hline R4 & b8 & b6 & b2 & b5 & b3 & b1 & b10 & b7 & b9 & b4 \\
\hline & \multicolumn{10}{|c|}{} \\
\hline R3 & b6 & b5 & b1 & b7 & b4 & b8 & b2 & b3 & b10 & b9 \\
\hline
\end{tabular}
\end{tabular}

Table 1. Variance analysis of measured traits in normal conditions

\begin{tabular}{|l|l|l|l|l|l|}
\hline \multicolumn{5}{|c|}{ average of squares } & \\
\hline $\begin{array}{l}\text { Harvest index } \\
\text { (Percent) }\end{array}$ & $\begin{array}{l}\text { grain yield } \\
\text { (tons per hectare) }\end{array}$ & $\begin{array}{l}\text { Biological yield } \\
\text { (tons per hectare) }\end{array}$ & $\begin{array}{l}\text { Plant } \\
\text { height }(\mathrm{cm})\end{array}$ & $\begin{array}{l}\text { Degree of } \\
\text { freedom }\end{array}$ & Source of changes \\
\hline 80.06 & 0.841 & 0.030 & 238.9 & 3 & Block \\
\hline $25.04^{*}$ & $0.316^{*}$ & $0.089^{*}$ & $88.82^{*}$ & 9 & Types \\
\hline 8.54 & 0.136 & 0.032 & 32.13 & 27 & Error \\
\hline 7.85 & 11.05 & 5.57 & 6.29 & - & $\begin{array}{l}\text { coefficient of variation } \\
\text { (\%) C.v }\end{array}$ \\
\hline $\begin{array}{l}\text { ns: Meaningless } \\
\text { *and**: Means significant at probability level of five percent }\end{array}$ & & & \\
\hline
\end{tabular}

due to low soil moisture and reduction in photosynthetic in plant to genetic potential for height, among others. Positive effect of irrigation on increasing plant growth and phenological stages in accordance with the environmental conditions and optimal use of resources in this process is also inferred.

In another experiment the effect of drought stress in plant height reduction is reported by Jafarzadeh (2004) that corresponded with the results of this study. One of the effects of water scarcity, reduction of inflammationmediated cell-cell defect in that it would reduce stem elongation and leaf photosynthesis in plants. Thus drought stress reduce stem height (Dixon et al., 2004), changes in plant height is usually the most obvious change is the result of growth in most crop plants. Plant
Height is also affected by environmental humidity and the main sign of water stress in vegetative stage reduction in the number and size of leaves. If the water shortage continues plant loss lower leaves and plant height will be significantly lower than normal (Flenet, 2003). Biological yield: Based on the results of the variance analysis data no significant differences between cultivars for biological yield in drought stress conditions is seen (Table 2).

As concluded from the table of mean comparisons Violeta has highest biological yield with the average $78 / 2$ tons per hectare and lowest average biological yield of 61.2 tons per hectare was achieved from Merzaga. It seems that due to favorable weather conditions the irrigation for the violeta has a positive effect on the

Table 2. Variance analysis of traits measured in drought

\begin{tabular}{l|l|l|l|l|l|}
\hline \multicolumn{5}{|c|}{ average of squares } \\
$\begin{array}{l}\text { Harvest index } \\
\text { Percent) }\end{array}$ & $\begin{array}{l}\text { grain yield } \\
\text { (tons per hectare) }\end{array}$ & $\begin{array}{l}\text { Biological yield } \\
\text { (tons per hectare) }\end{array}$ & Plant height (cm) & $\begin{array}{l}\text { Degree of } \\
\text { freedom }\end{array}$ & Changes source \\
\hline 159.30 & 2.71 & 0.833 & 37.46 & 3 & Block \\
\hline $27.26 \mathrm{~ns}$ & $0.35 \mathrm{~ns}$ & $0.076 \mathrm{~ns}$ & $44.26^{*}$ & 9 & Types \\
\hline 30.54 & 0.29 & 0.118 & 15.61 & 27 & Error \\
\hline 19.02 & 25.13 & 4.83 & - & $\begin{array}{l}\text { coefficient of } \\
\text { variation (\%)C.v }\end{array}$ \\
\hline $\begin{array}{l}\text { ns: Meaningless } \\
\text { *and**: Means significant at probability level of five percent }\end{array}$ & 13.19 & &
\end{tabular}




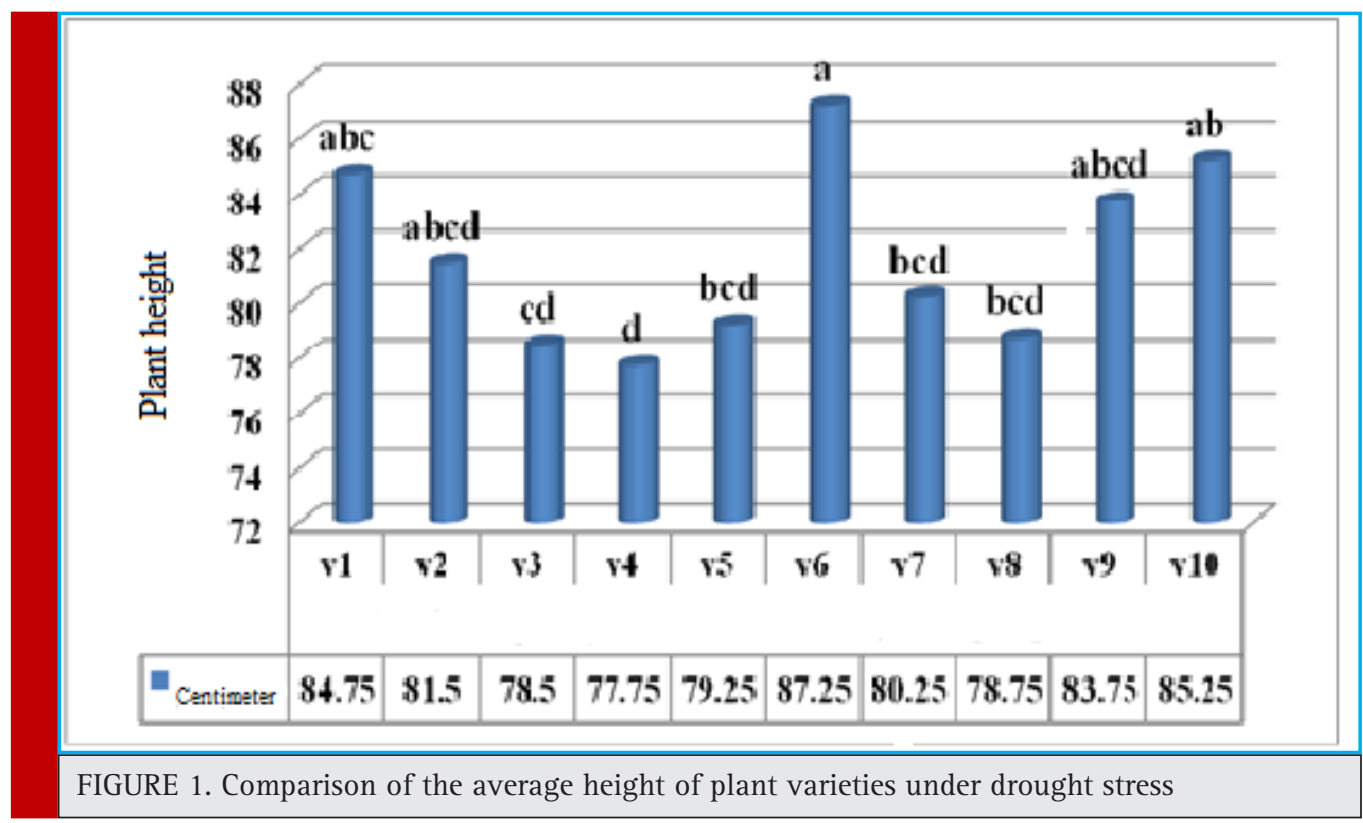

growth and caused the maximum length and height. The increase in height and growth cause increased leaf area and thereby cause an increase in photosynthesis and higher dry matter production and yield will result. Accordingly, most biomass is also observed in this treatment. Probably tensions through reduced plant height, which is result of high sensitivity the process of division and cell growth to drought stress cause decrease in rate of non-structural carbohydrates stored in the stems, reduced leaf area and photosynthesis is reduced and as a result, plant fresh weight is decreased.

The test results also complies with Barut Zadeh etal. (2008). If lack of water caused by drought and lack of rainfall in the growing season continues, plant encounters with lower growth in vegetative and reproductive growth stages. During the period of reproduction, stems are active tank for dry matter and perhaps other nutrients (Edalatian, 2008). Frbvdnya (2004) reported that drought stress in vegetative and reproductive growth stages reduced biological yield.

\section{GRAIN YIELD}

Grain yield is function of the three parameters: clusters per square meter, number of grains per spike and

\begin{tabular}{|c|c|c|c|c|}
\hline Harvest index (percent) & $\begin{array}{l}\text { Grain yield (tons per } \\
\text { hectare) }\end{array}$ & $\begin{array}{l}\text { Biological yield (tons } \\
\text { per hectare) }\end{array}$ & $\begin{array}{l}\text { Plant height } \\
(\mathrm{cm})\end{array}$ & $\begin{array}{l}\text { Experimental } \\
\text { treatments }\end{array}$ \\
\hline \multicolumn{5}{|c|}{ Types } \\
\hline $29.50 a$ & $2.50 \mathrm{ab}$ & $2.71 \mathrm{a}$ & $84.75 a b c$ & Type 1 \\
\hline $28.75 \mathrm{a}$ & $2.13 \mathrm{ab}$ & $2.64 \mathrm{a}$ & 81.50abcd & Type 2 \\
\hline $27 \mathrm{a}$ & $1.93 \mathrm{ab}$ & $2.45 \mathrm{a}$ & $78.50 \mathrm{~cd}$ & Type 3 \\
\hline $25.75 a$ & $1.76 \mathrm{~b}$ & $2.34 \mathrm{a}$ & $77.75 \mathrm{~d}$ & Type 4 \\
\hline $27.75 \mathrm{a}$ & $2.03 \mathrm{ab}$ & $2.61 \mathrm{a}$ & $79.25 \mathrm{bcd}$ & Type 5 \\
\hline $33.75 a$ & $2.38 \mathrm{ab}$ & $2.78 \mathrm{a}$ & $87.25 \mathrm{a}$ & Type 6 \\
\hline $28.50 \mathrm{a}$ & $2.06 \mathrm{ab}$ & $2.63 a$ & $80.25 \mathrm{bcd}$ & Type 7 \\
\hline $27 a$ & $1.98 \mathrm{ab}$ & $2.51 \mathrm{a}$ & 78.75bcd & Type 8 \\
\hline $29.25 \mathrm{a}$ & $2.16 \mathrm{ab}$ & $2.69 \mathrm{a}$ & 83.75abcd & Type 9 \\
\hline $33.25 \mathrm{a}$ & $2.76 \mathrm{a}$ & $2.73 \mathrm{a}$ & 85.25ab & Type 10 \\
\hline
\end{tabular}




\begin{tabular}{|l|l|l|l|l|l|}
\hline \multicolumn{6}{|l|}{ Table 4. Variance analysis of measured traits in drought condition } \\
\hline $\begin{array}{l}\text { Source of } \\
\text { changes }\end{array}$ & $\begin{array}{l}\text { Source of } \\
\text { changes }\end{array}$ & $\begin{array}{l}\text { Source of } \\
\text { changes }\end{array}$ & $\begin{array}{l}\text { Source of } \\
\text { changes }\end{array}$ & $\begin{array}{l}\text { Source of } \\
\text { changes }\end{array}$ & Source of changes \\
\hline 40.84 & 134.2 & 304.7 & 171090.4 & 3 & Block \\
\hline $11.08 \mathrm{~ns}$ & $131.2^{*}$ & $117.3^{*}$ & $12168.5 \mathrm{~ns}$ & 9 & Types \\
\hline 11.46 & 52.99 & 38.34 & 11256.4 & 27 & Error \\
\hline 7.98 & 11.72 & 13.24 & 19.85 & - & $\begin{array}{l}\text { coefficient of variation } \\
\text { (\%) C.v }\end{array}$ \\
\hline $\begin{array}{l}\text { ns: Meaningless } \\
\text { *and**: Means significant at probability level of five percent }\end{array}$ & \multicolumn{4}{l}{} \\
\hline
\end{tabular}

thousand kernel weight. Multiple factors such as moisture levels can be effective in improving the quality and quantity of grain (Arshi, 2004). Based on the results of data analysis no significant differences between cultivars for grain yield in drought stress conditions is seen (Table 3). As can be deduced by comparisons of mean grain yield of violeta with an average of 2/38 tons per hectare and the lowest yield was obtained from the Merzaga with an average of 2/03 tons per hectare, which can be caused by growth reduction and yield components for these types.

Harvest index: harvest index shows efficiency in distribution of photosynthetic products in to grain in plants. Based on the results of the variance analysis no significant differences among varieties for harvest index under drought stress conditions is seen (Table 2). As concluded from table of comparisons of mean harvest index, highest harvest index was obtained from violeta with the average of 75/33\% and the lowest harvest index was obtained from the Merzaga with an average of 75/27 \% (Table 3). In other words, additional plant dry matter does not produce, but a large part of the grain dry matter allocated to economic performance.

A plant performance can be increased by increasing the share of total dry matter production on the farm or raise economic performance (Koochaki and Srmdnya, 1993).

The number of clusters per square meter: based on the results of data analysis no significant difference between the figures for the number of clusters per square meter in drought stress conditions is seen (Table 4). However, based on what can be inferred from the table of mean comparisons Violeta had largest number of clusters per square meter and the average cluster was 2/606 due to the proper humidity conditions. The lowest number of clusters per square meter was an average of 2/486 cluster numbers for Merzaga (Table 4). Goksoy etal. (Goksoy et al., 2004) concluded that the stress test results face significant reduction in the number of heads.

Grain number: the number of grains per panicle one of the most important factors in increasing the performance of the barely. Drought stress by reducing the leaf

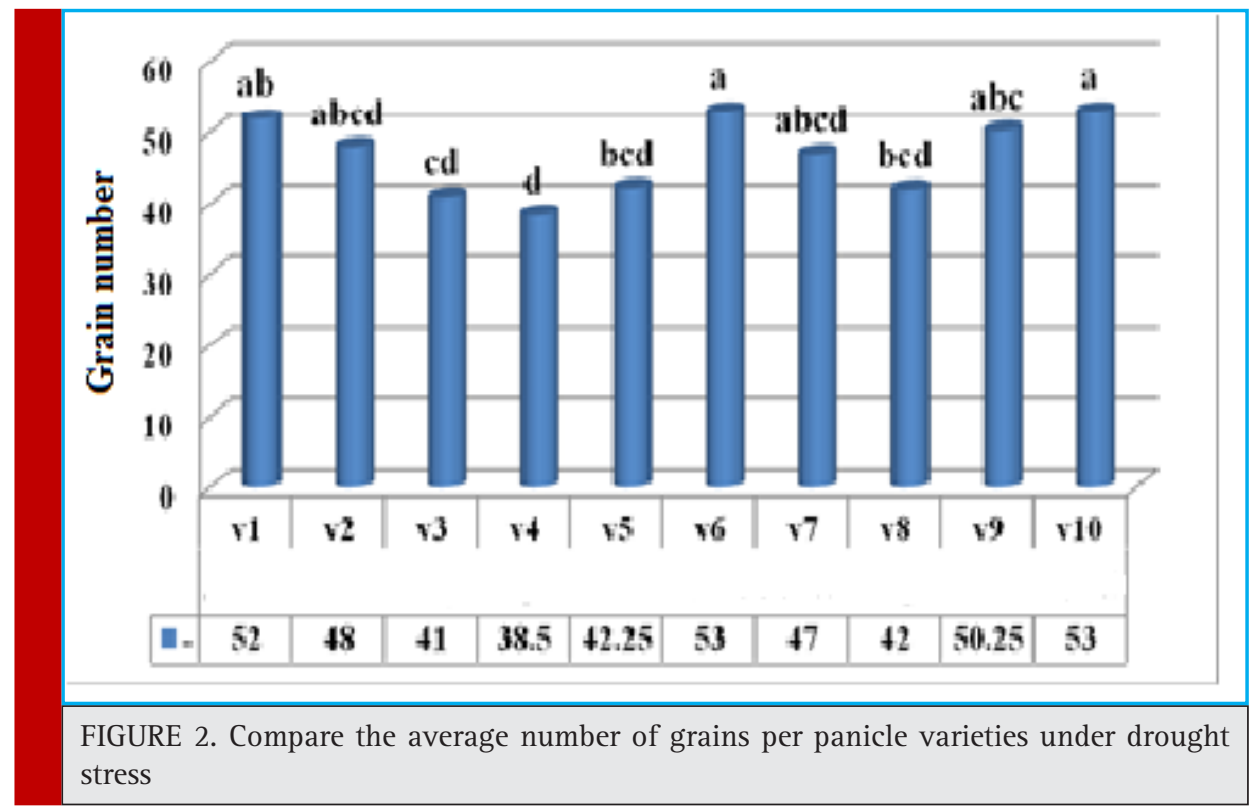




\begin{tabular}{|c|c|c|c|c|}
\hline $\begin{array}{l}\text { Thousand Seed } \\
\text { weight (g) }\end{array}$ & $\begin{array}{l}\text { Panicle length } \\
(\mathrm{cm})\end{array}$ & $\begin{array}{l}\text { The number of } \\
\text { grains per panicle }\end{array}$ & $\begin{array}{l}\text { The number of clusters } \\
\text { per square meter }\end{array}$ & $\begin{array}{l}\text { Experimental } \\
\text { treatments }\end{array}$ \\
\hline \multicolumn{5}{|c|}{ Types } \\
\hline $43.37 \mathrm{a}$ & 66.75abc & $52 \mathrm{ab}$ & $585 a$ & Type 1 \\
\hline $43.13 a$ & 61abcd & 48abcd & $547 a$ & Type 2 \\
\hline $40.35 a$ & $56.75 \mathrm{~cd}$ & $41 \mathrm{~cd}$ & $468.2 \mathrm{a}$ & Type 3 \\
\hline $39.97 a$ & $54 d$ & $38.50 d$ & $462.2 \mathrm{a}$ & Type 4 \\
\hline 41.48a & 58.75bcd & $42.25 \mathrm{bcd}$ & $486.2 \mathrm{a}$ & Type 5 \\
\hline $45.35 \mathrm{a}$ & $72 \mathrm{a}$ & $53 a$ & $606.2 \mathrm{a}$ & Type 6 \\
\hline $42.23 a$ & $60.25 a b c d$ & 47abcd & $539 a$ & Type 7 \\
\hline $41.13 \mathrm{a}$ & $57.50 \mathrm{bcd}$ & $42 \mathrm{bcd}$ & $482.2 \mathrm{a}$ & Type 8 \\
\hline $43.22 \mathrm{a}$ & $64.25 \mathrm{abcd}$ & $50.25 \mathrm{abc}$ & $576.7 \mathrm{a}$ & Type 9 \\
\hline $43.64 a$ & $69 a b$ & $53 a$ & 589.7a & Type 10 \\
\hline
\end{tabular}

area cause photosynthetic source to reduce and loss of enzyme activity influencing this process (Koochaki, 2003). Results of variance analysis showed a significant difference between the types in the number of grains in drought stress conditions in a five percent statistical level (Table 4). As can be inferred from the table of mean comparisons largest number of grains per panicle is for the violeta, averaging 53 seeds and the lowest number of grains per panicle is for Merzaga with an average grain of 25/42, respectively (Figure 2).Studies have shown that drought stress reduced the number of grains per ear and weight of thousand grains. (Kazempour and Tajbakhsh, 2002)

It seems stoping irrigation at flowering stage is effective in reducing flower-producing cells and ultimately affect their fertility, so that its effect in reducing the number of seeds per head has been revealed. The number of seeds per head is reduced with increasing water stress significantly. The obtained results correspond with the results of Gomez et al (Gomez et al., 2003) and Goksoy et al. (Goksoy et al., 2004) that reported reduction in number of seeds per head under water stress.

Panicle length: panicle length, is affected by grain number in panicle thereby is effective in increasing the yield. The results of variance analysis of data showed significant differences among cultivars in the cluster length under drought stress conditions in a statistical level of five percent (Table 4). As interpreted from table of mean comparisons maximum panicle length of 72 $\mathrm{cm}$ was for violeta the minimum number of grains per

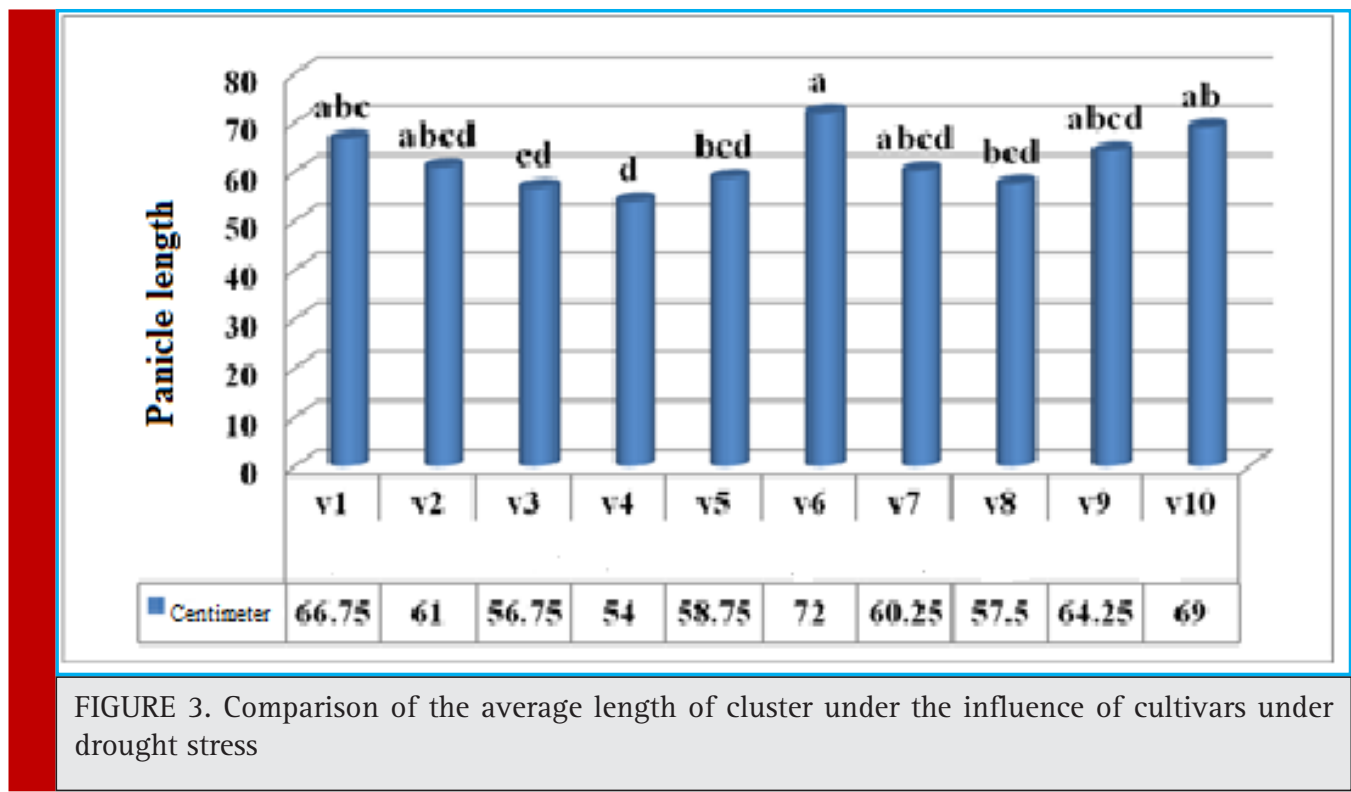


Table 6. Correlation of measured traits for barley cultivars under drought stress

\begin{tabular}{l|l|l|l|l|l|l|l|l|}
\hline $\begin{array}{l}\text { Thousand } \\
\text { Kernel } \\
\text { Weight }\end{array}$ & $\begin{array}{l}\text { Panicle } \\
\text { length }\end{array}$ & $\begin{array}{l}\text { Number of } \\
\text { grains per } \\
\text { panicle }\end{array}$ & $\begin{array}{l}\text { Spikes per } \\
\text { square } \\
\text { meter }\end{array}$ & $\begin{array}{l}\text { Harvest } \\
\text { index }\end{array}$ & $\begin{array}{l}\text { Grain } \\
\text { yield }\end{array}$ & $\begin{array}{l}\text { Biological } \\
\text { yield }\end{array}$ & $\begin{array}{l}\text { Plant } \\
\text { height }\end{array}$ & Traits \\
\hline & & & & & & & 1 & 1 \\
\hline & & & & & & & $0.68^{* *}$ & 2 \\
\hline & & & & & & 1 & 0.22 & 3 \\
\hline & & & & 1 & $0.97^{* *}$ & $0.42^{*}$ & 0.18 & 5 \\
\hline & & & 1 & $0.36^{* * *}$ & $0.43^{* *}$ & 0.18 & $0.31^{*}$ & 6 \\
\hline & & 1 & 0.55 & $0.59^{* *}$ & $0.51^{* *}$ & 0.26 & 0.14 & 7 \\
\hline & 1 & $0.73^{* *}$ & $-0.41^{* * *}$ & 0.28 & $0.39^{*}$ & 0.22 & 0.19 & 8 \\
\hline 1 & -0.19 & -0.28 & $0.56^{* * *}$ & $0.71^{* *}$ & $-0.43^{*}$ & -0.17 & 0.08 & 9 \\
\hline $\begin{array}{l}\text { ns: Meaningless } \\
\text { "and**: Means significant at probability level of five percent }\end{array}$ & & & & & \\
\hline
\end{tabular}

panicle was for Merzaga with an average of 75/58 cm, respectively (Figure 3).

It seems water stress in vegetative growth stages, reduce the leaf area index and absorption and transport of nutrients and changes the yield components and grain yield (Baroot Zadeh et al., 2010), The findings of Sakizade (2003), stated that under water stress grain yield decreased is consistent with findings of this study. Outter et al (Outter et al., 2007), reported that drought stress reduced grain yield in corn and this reduction correlated with a decrease in the number of seeds despite to the weight of the grains. Drought stress was clearly defined by its impact on the reduction of biomass growth, reduced yield components and ultimately grain yield (Ardalan et al., 2012).
Paknezhad etal. (2006), in the same test reported that drought had a significant effect on grain yield and yield components and severe stress caused 37 percent yield decrease. Ec (Eck, 2004), also in his studies confirmed that a 2-week and 4-week stress during vegetative growth, respectively, decreased performance by 23 percent and 46 percent. Chapman et al (Chapman et al., 2007), reported a decrease of $17 \%$ and $80 \%$ reduction in the average stress and severe tensions respectively. Ahmadi et al. (2010), also in the same trial reported that most of the traits showed a negative reaction to stress that was the greatest effect on performance due to the sharp decline in the number of grains per ear, ear length and grain weight. The weight of one thousand seeds:

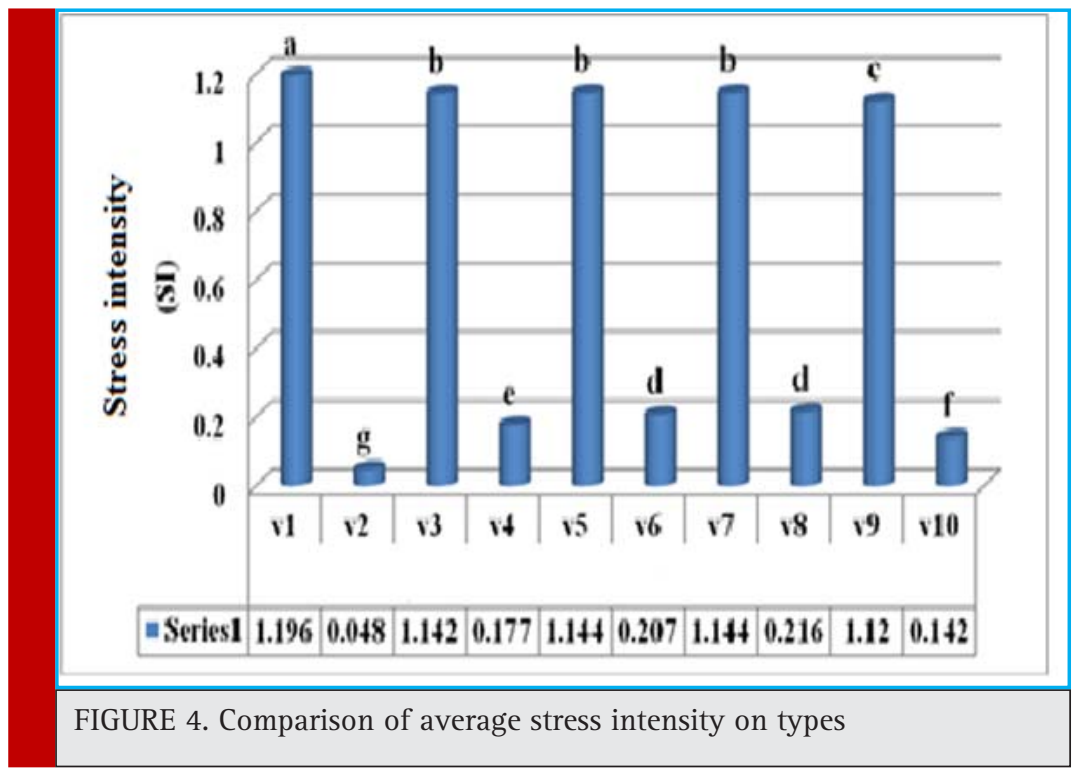




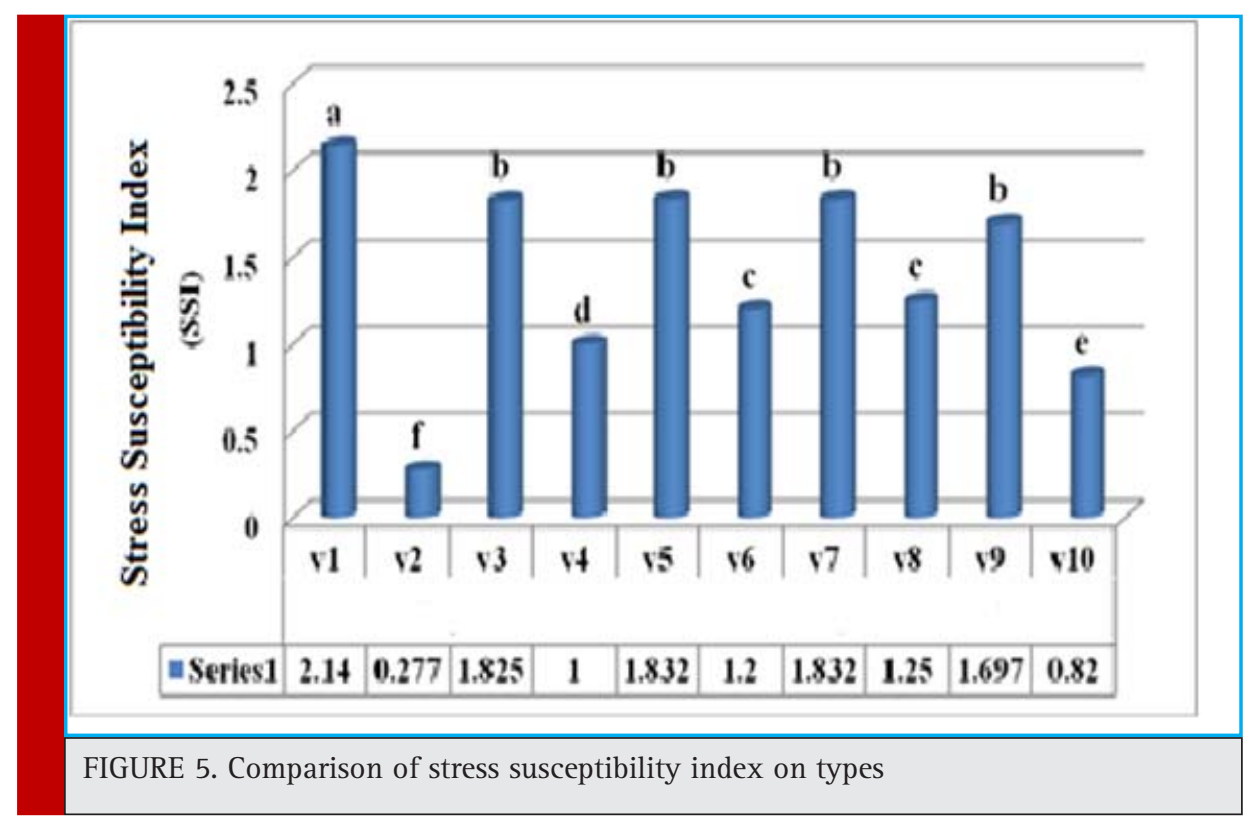

No significant differences among varieties for seed weight under drought stress conditions (Table 4). However, based on what can be inferred from the table of mean comparisons Violeta has highest average seed weight with 35/45 grams and Merzaga with lowest seed weight with an average of 48/41 grams were obtained (Table 5). Because it can reduce the impact of water scarcity and Smylaty material transport to grain. It seems that the lack of photosynthetic material in case of drought can cause thousand grain weight not to reach its maximum potential limit. Grain weight is function of its filling period and speed that is provided form two sources of current photosynthesis and remobilization of the plant food storage. Lack of soil moisture during the growing season, especially in the reproductive stage reduce current photosynthesis, rate and duration of grain filling and the weight of it. However, environmental stress such as drought stress, increases remobilization of supply from secondary sources (stems and petioles) to the reservoir (seeds) but cannot compensate reduction in current photosynthesis due to lack of soil moisture.

3-3. Correlation of measured traits for barley cultivars under drought stress

As can be seen in measured traits correlation table (Table 6) in barley cultivars, there is a significant positive correlation between biological yield and grain yield.

\begin{tabular}{|c|c|c|c|c|c|c|}
\hline HARM & GMP & MP & STI & TOL & SSI & $\begin{array}{l}\text { Experimented } \\
\text { Treatments }\end{array}$ \\
\hline \multicolumn{6}{|c|}{ Types } & \\
\hline 3.767 & 3.797 & 3.835 & 1.922 & 1.855 & 2.140 & Type 1 \\
\hline 3.550 & 3.550 & 3.550 & 1.110 & 0.170 & 0.277 & Type 2 \\
\hline 3.745 & 3.760 & 3.782 & 1.900 & 1.585 & 1.825 & Type 3 \\
\hline 2.990 & 3.010 & 3.025 & 0.800 & 0.590 & 1 & Type 4 \\
\hline 3.220 & 3.235 & 3.250 & 1.585 & 1.480 & 1.832 & Type 5 \\
\hline 2.670 & 2.690 & 2.710 & 0.640 & 0.630 & 1.200 & Type 6 \\
\hline 3.362 & 3.377 & 3.392 & 1.667 & 1.510 & 1.832 & Type 7 \\
\hline 3.280 & 3.310 & 3.330 & 0.970 & 0.810 & 1.250 & Type 8 \\
\hline 3.392 & 3.092 & 3.100 & 1.600 & 1.367 & 1.697 & Type 9 \\
\hline 1.610 & 1.620 & 1.620 & 0.230 & 0.250 & 0.820 & Type 10 \\
\hline
\end{tabular}




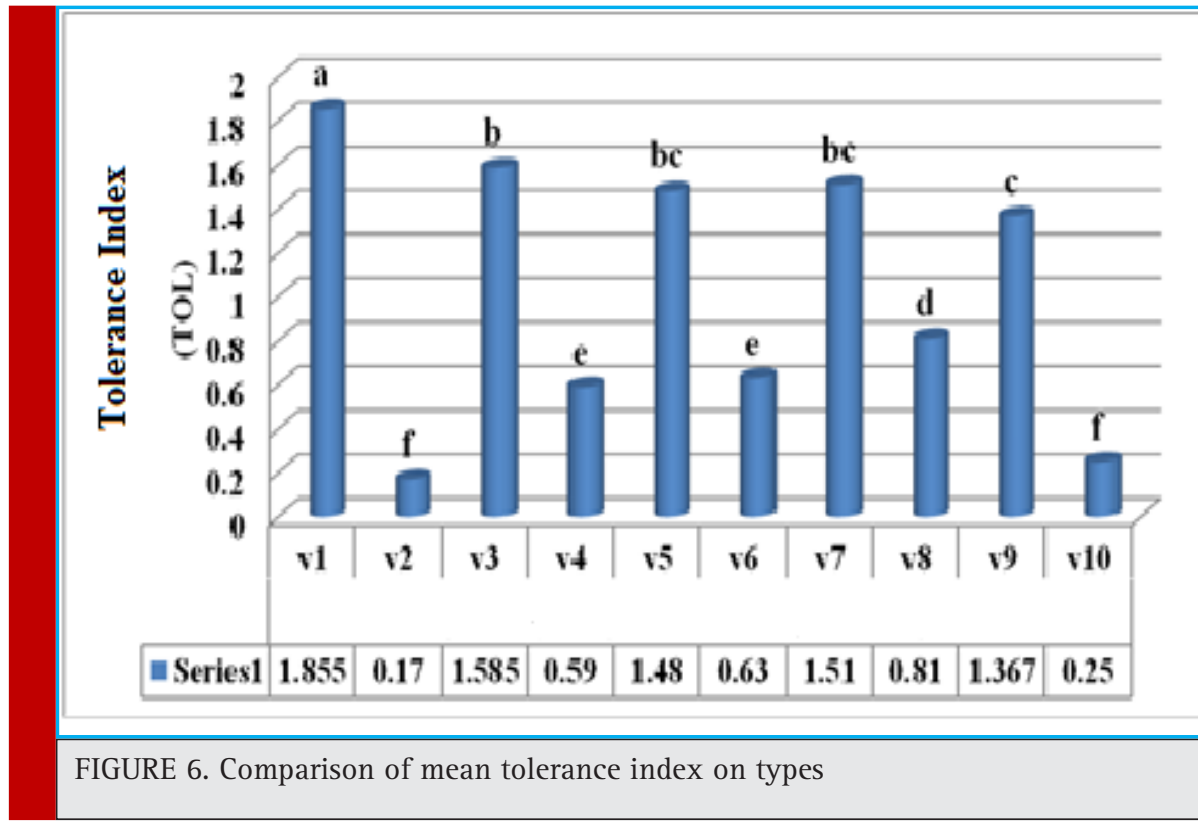

Also there was a significant positive correlation between plant height and grain yield and harvest index. In addition there is a significant positive correlation between grain yield and harvest index. While there is a significant positive correlation between yield and number of grains per panicle with the number of clusters.

\section{3-4. Effects of water stress index for barley}

Stress intensity (SI): The results of variance analysis shows that the stress intensity significant effect on type on the statistical level of one percent (Table 7). As can be inferred from the table of mean comparisons, maximum stress is for the Zahak with an average of 196/1 and minimum stress is for the lingnee with an average of 048/0, respectively (Figure 4).

\section{Stress Susceptibility Index (SSI)}

It can be concluded from the table of mean comparisons that maximum stress susceptibility index for the Zahak is with an average of $140 / 2$ and the minimum stress is for the lingnee with an average of $277 / 0$, respectively (Figure 5).

Tolerance Index (TOL): As can be inferred maximum tolerance index is for Zahak with an average of 855/1 and the lowest tolerance index is for the lingnee with an average of 170/0, were obtained (Figure 6).

Stress Tolerance Index (STI): As inferred, maximum stress tolerance is for the Zahak with an average of $922 / 1$ and the lowest tolerance index is for the Brs180 with an average of 230/0, respectively (Figure 7).

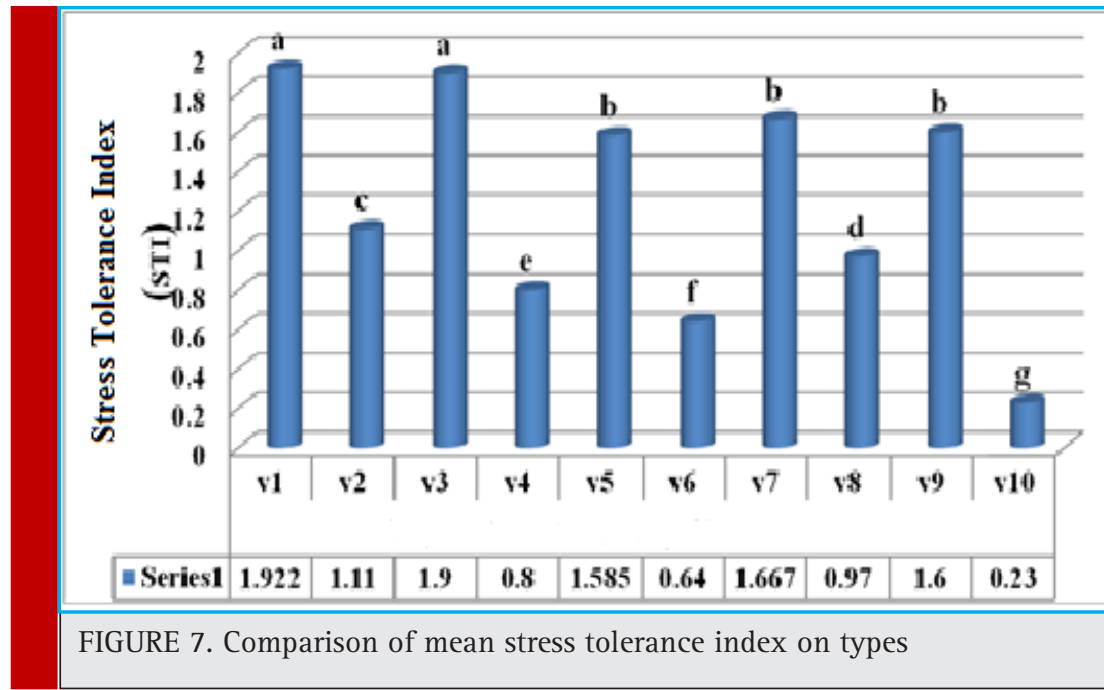




\section{CONCLUSION}

The results of variance analysis of measured traits showed that in normal conditions the measured traits in barley were significant except thousands grain weight and spikes per square meter.The highest biological yield (52.3 tons per hectare), grain yield (90.3 tons per hectare) and harvest index (40\%) was obtained from the lingnee. Also the lowest biological yield (08/3 tons per hectare), grain yield (96/2 tons per hectare) and harvest index (25/34 percent) was observed for the L.1242. The effect of measured traits of barley varieties under drought stress were significant only on plant height, number of grains per panicle and panicle length, In a way that the maximum height $(25 / 79 \mathrm{~cm})$, number of grains per panicle (53) and panicle length $(72 \mathrm{~cm})$ of Violeta was obtained. Also, the minimum height $(25 / 87 \mathrm{~cm})$, number of grains per panicle (25/42) and panicle length (75/58 $\mathrm{cm})$ was observed for the Merzaga. In addition to this mean squared of drought stress indices for barley varieties on traits such as drought stress intensity (SI), stress susceptibility index (SSI), Tolerance Index (TOL), stress tolerance index (STI), efficiency index medium (MP), geometric mean productivity (GMP) and harmonic mean (HARM) was significant. The highest values of mentioned traits was for the Zahak in common. The lowest stress (SI), stress susceptibility index (SSI), Tolerance Index (TOL) to the lowest Lingnee and stress tolerance index (STI), mean productivity (MP), geometric mean productivity (GMP) and the harmonic mean (HARM) was observed for the Brs180. It seems that due to the favorable climatic conditions of this irrigation treatment for the Lingnee had a positive effect on growth and caused maximum length and height of this type. The increase in height and growth will increase leaf area and thereby cause an increase in photosynthesis which will result higher dry matter production and yield. Accordingly, the maximum biomass is observed in this treatment. It could be said that higher biological yield of Lingnee is because of its genetic and physiological traits that is associated with the period of further growth and production of tillers. Higher grain yield than other cultivars in Lingnee is because of higher yield components in this type. Since the yield of plants is influenced by cultivar and environmental conditions, it can be said that plants reaction about the yield and yield components is mostly affected by numerous factors including the type of plant, growth period, soil texture, soil fertility status and weather conditions. It seems genetic potential of Lingnee, through a greater impact on increasing the economic yield of the biomass has been able to raise the value of the harvest index in this type. In other words, plant does not produce additional dry matter, but a large part of the economic yield is allocated to economic performance of grain. Based on stress tolerance index (STI) Zahak varieties is one of the types with highest tolerance to drought stress. Finally, it is suggested that more varieties will be examined and sustainability indices be used in these experiments.

\section{REFERENCES}

Ahmed, J. Zeynali Khangah, H. Rostami, M. And Choukan, $R, 2010$. Evaluation of drought resistance in corn hybrids late trade. Iranian Journal of Agricultural Sciences, Issue 4, Pages 899-891.

Ardalan, V. Aghayari, F. Paknejad, P. Sadeghi Shoa, D. IsmailZadeh Khorasani, N. And Fatemi Rekia, Z, 2014. Effect of deficit irrigation and irrigation practices on yield and yield components of two maize varieties. Journal of Agriculture and Plant Breeding. Volume 8, Issue 3, pp. 189- 175.

Arshi. Y, 1994. Sunflower Science and Technology (Translation). The Head Office of Iranian oil, cotton and grain. 717 pp.

Bradford, k.j.2004. water stress and the water relation of seed development. A critical Review. Cropsci.

Chapman, S. C., Crossa, K. Basford, E. and Kroonenberg, P. M. 2007. Genotype by environment effects and selection for drought tolerance in tropical maize: Three - mode pattern analysis. Euphytica 95 (1): 11-20.

Dixon, F. L. and L. Luteman. 2004. Effects_of_drilling_date on growth and yield of sunflower in the U.K. J. Agri. Sci. 19 (2): 197-204.

Eck, H.V. 2004.Irrigatied corn yield response to nitrogen and water. Agronomy Journal 76 (3): 421-428.

Farbodnia, T. 2005. Effects of water stress on germination, growth and some biochemical changes caused by tension in the Iranian chickpea. Master of Science thesis in Biology Plant Sciences. Tarbiat Moallem University of Tehran.

Fard, E. M., Bakhshi, B., Keshavarznia, R., Nikpay, N., Shahbazi, M., \&t Salekdeh, G. H. (2017). Drought responsive microRNAs in two barley cultivars differing in their level of sensitivity to drought stress. Plant Physiology and Biochemistry. 118, $121-129$

Flenet .F. 2003 . Partitioning of stored and current assimilates in sunflower as influenced by timing of water stress . Agricultural Meditterranea . 127 (4) : 306-312 .

Goksoy, A. T., A. 0. Demir, Z. M. Turan and N. Dagustu.2004. Responses of sunflower to full and Limited irrigation at different growth stages. Filed Crops Res. 87: 167-178.

Gomez , D., O.Marinez ., M.Arnon ., and Castro. L. 2003 . Generating a selection index for drought tolerance in sunflower . II. Water use and consumption . Helia . 15 : 65-70 .

Jafarzadeh Knarsry, M \&t Poostini, K. 2004. Effects of water stress in different growth stages on some morphological characteristics and yield components of sunflower, Iranian Journal of Agriculture Science, Volume: 29 .No 2, pp. 353- 361.

Javadi, T., Rohollahi, D., Ghaderi, N., \&t Nazari, F. (2017). Mitigating the adverse effects of drought stress on the morpho- 
physiological traits and anti-oxidative enzyme activities of Prunus avium through $\beta$-amino butyric acid drenching. Scientia Horticulturae, 218, 156-163.

Kazempour, S. Tajbakhsh, M. 2001. Some anti-transpiration effect on growth characteristics, yield and yield components of maize under limited irrigation. Iranian Journal of Agricultural Sciences. Vol 33 (2): 211-205.

Koochaki, A. 2003. Organic farming of Esfarzeh and Pytaniom in response to water stress. Iran arable Journal, No 2 (1), pp. 111-103.

Paknezhad, F, 2000, Evaluation and comparison of the performance of different forage sorghum hybrids in different den- sities, Crop Science Society of Iran. Iranian Journal of Crop Sciences. Volume III. No 1, pp. 32 to 37.

Sarmadnia, Gh.h and Koochaki A, 2002. Crop Physiology (Translation). Mashhad University, Jahad Daneshgahi Press.

Sheikh Atabak, A, 2004. The effect of drought on physiological characteristics and activity of antioxidant enzymes in pea varieties. Master's thesis.

Simane, B., J. M. peacock, and p.c struik.2003. Differences in developmental plasti city and growth rate among drought resistant and susceptible cultivars of durum wheat. Plant and soil- 157:155-166. 